\title{
HIGH-ENERGY EVENTS AND SHORT-TERM CHANGES IN SUPERFICIAL BEACH SEDIMENTS
}

\author{
Eduardo Siegle ${ }^{l}$ and Lauro J. Calliari ${ }^{2}$ \\ ${ }^{1}$ Instituto Oceanográfico da Universidade de São Paulo \\ (Praça do Oceanográfico, 191, 05508-120 São Paulo, SP, Brasil) \\ esiegle@io.usp.br \\ ${ }^{2}$ Laboratório de Oceanografia Geológica, Fundação Universidade Federal do Rio Grande \\ (Av. Itália, km 8, Campus Carreiros, 96201-900 Rio Grande, RS, Brasil) \\ lcalliari@log.furg.br
}

The sediment distribution along modern beaches is the result of the complex interaction between the sediment source, the wave energy level and the general offshore slope upon which the beach is constructed (KOMAR, 1998). Sediments tend to be sorted according to the energy levels that the beach is exposed, so that beaches exposed to higher wave energy levels are expected to be composed by coarser sediments. In the composition of beach sediments, quantities of heavy minerals might be present. Since they are denser than quartz grains, they present a different hydraulic behaviour when compared to lighter grains. The behaviour of heavy minerals has been studied mainly related to erosional and/or accretional beach processes (e.g. SLINGERLAND, 1977; KOMAR et al., 1989; KOMAR, 1998).

The straight wave-dominated southernmost coastline of Brazil is characterised by an extensive sandy coastal plain. The study area comprehends 220 $\mathrm{km}$ of sandy beaches located between the Patos Lagoon inlet and the Uruguayan border (Fig. 1). Beaches in this region are classified as dissipative and intermediate, associated to one or two longshore sandbars (CALLIARI; KLEIN, 1993). Seasonal variations are present, with accretion profiles during spring and summer and erosion profiles during autumn and winter. The climate of this coastal region is under the control of the high-pressure centre of the Atlantic anticyclone, whose latitudinal migration and the passage of polar front systems in 6-10 days intervals have a seasonally modifying influence on the climate. During cold fronts events, more common during winter months, SW winds become stronger $\left(8 \mathrm{~m} . \mathrm{s}^{-1}\right.$ mean velocity) resulting in high water levels on the coast. Tides in the southern portion of Brazil have a minimal influence, with mean range of $0.47 \mathrm{~m}$. In this way, the major variations in water level are due to meteorological factors, such as wind and atmospheric pressure, causing storm surges very relevant to the coastline.

Previous studies, such as Calliari et al. (1998), show the morphological response of the

$\overline{\text { Contr. No. } 875}$ do Inst. oceanogr. da Usp. beaches in the study area to the passage of cold fronts. The storm surge caused by the strong winds is shown to be highly erosive, causing beach erosion and dune retreat at rates of the order of $63 \mathrm{~m}^{3} \mathrm{~m}^{-1}$ and $3 \mathrm{~m}$, respectively. These authors relate the different erosion rates along the coast to the coastline orientation and beach characteristics, with higher erosion rates towards the south.

Owing to the complexity of this dynamic environment, the objective of this study is to verify the influence of the cold front passages with the associated high wave energy and storm surge, on the superficial beach sediment characteristics. Therefore, a total of 88 beach samples were collected during two field campaigns in August (18th) and September (15th) 1995, before and after the passage of an intense cold front. Samples were collected at the beachface and at the backshore, with a longshore interval of $10 \mathrm{~km}$. All samples were submitted to standard procedures of grain size analysis ( $1 / 4$ phi sieving interval), heavy mineral and carbonate quantification. Data was statistically analysed according to Folk and Ward (1957) in terms of mean grain size, standard deviation, skewness and heavy mineral and carbonate concentrations.

Averaged mean grain size results, for beachface and swash limit zone, show that the study area can be divided in three major regions: 1) very fine sand close to the Patos Lagoon inlet, 2) coarser sediments to the south of the Albardão lighthouse, and $3)$ an intermediate region with fine sand between regions 1 and 2 (Fig. 1).

The main factor that controls this sediment grading along the coast is the source area of the sediments. The fine material adjacent to the Patos Lagoon inlet presents a large amount of sediments of the same classes of the ones found in the estuarine portion of the lagoon by Calliari (1980). Coarsest grain sizes are found in the southern portion of the study area, close to the Albardão lighthouse (Fig. 1). According to Figueiredo (1975) and Calliari and Klein (1993), this region is influenced by fluvial deposits, probably from the pleistocene, found at the inner shelf. These deposits present coarse terrigenous sediments, 
with angular quartz grains. The middle portion of the study area is composed by fine sand, and is not influenced by any modern source area, resulting in well sorted grains. This shows that the alongshore sediment distribution in this region is a direct consequence of the source areas, with the dominant fine sands being influenced only by fine sediments supplied by the Patos Lagoon and coarse sediments deposited on the beach as a result of the reworking of fluvial deposits in the inner shelf. Despite this alongshore distribution influenced by large scale phenomena, the sampling strategy applied here shows that there is a small scale difference in grain size distribution and sediment composition inside each of these regions as a consequence of the energetic level of the hydrodynamic conditions.
During the one month interval between the two field campaigns, three cold fronts affected the region, being the $7^{\text {th }}$ to $9^{\text {th }}$ of September event the most prominent (Fig. 2) and with more importance to this study since it occurred just a few days before the second sampling campaign. The synoptic situation of this event was characterized by a low pressure centre moving along the western Atlantic Ocean, resulting in a long fetch and wave propagation along the Argentinean, Uruguayan and south Brazilian coasts (Fig. 2). Pressure gradients in the order of $30 \mathrm{mb}$ resulted in strong winds generating waves and the storm surge which coincided with spring tides in the region.

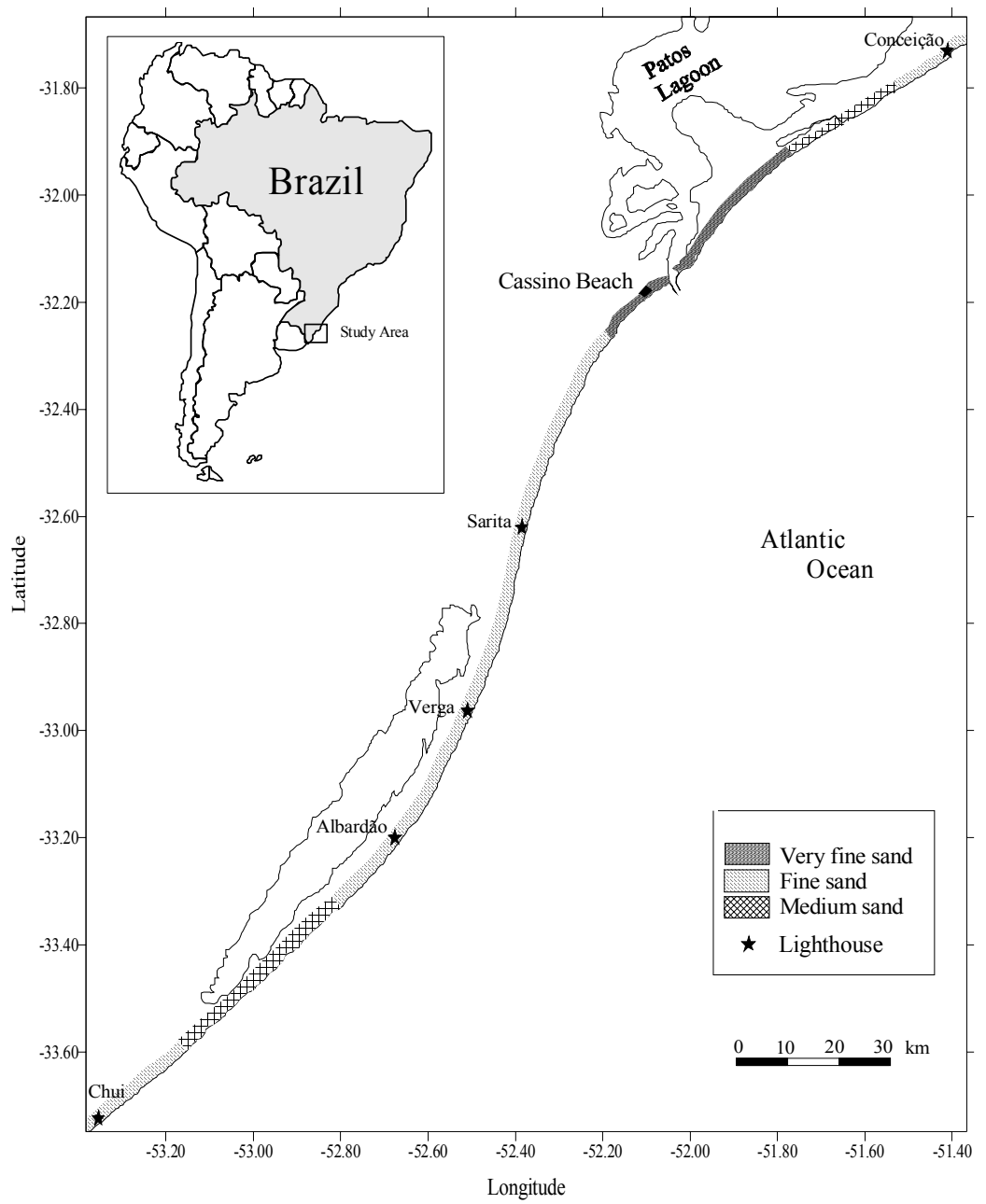

Fig. 1. Study area, between Cassino Beach and Chuí, and the beach average mean sediment size distribution. 

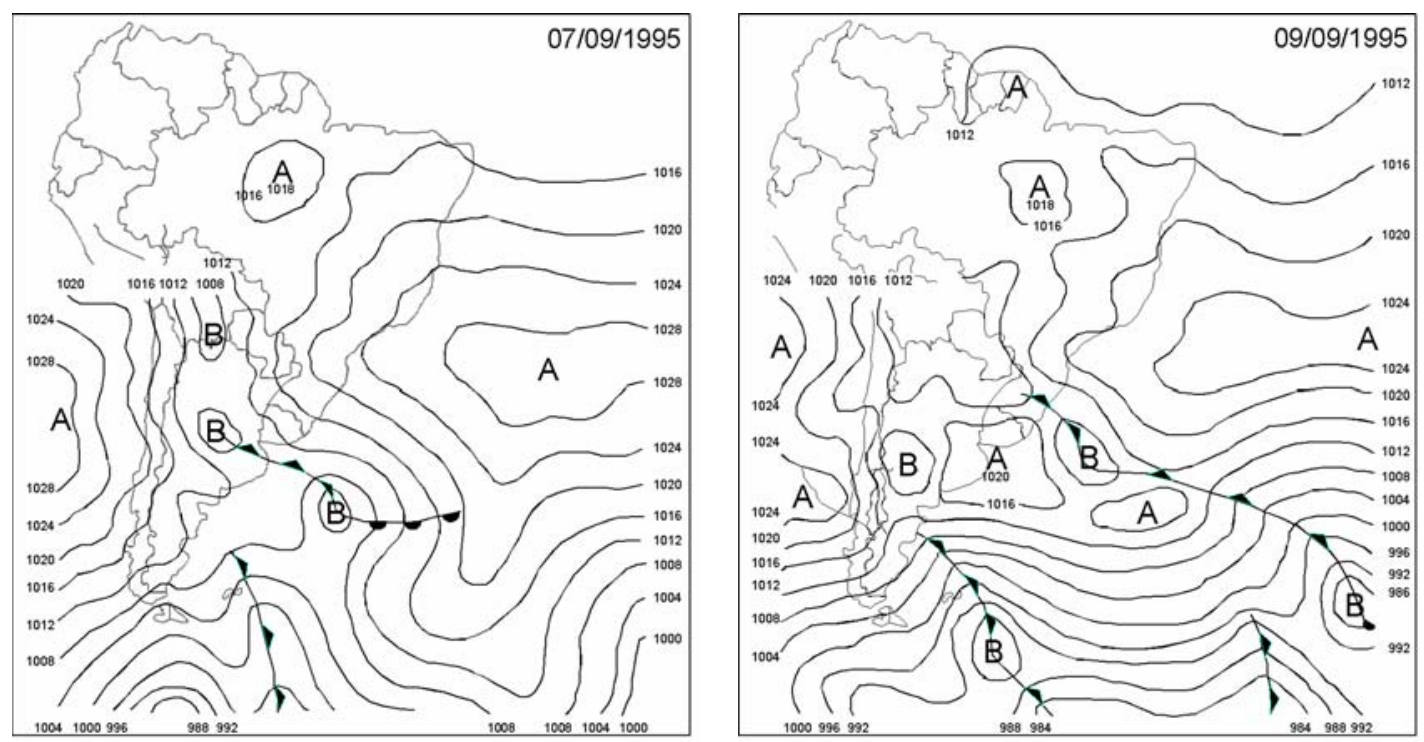

Fig. 2. Barometric pressure charts for September 7th and $9^{\text {th }}, 1995$ recording the passage of a cold front over the Rio Grande do Sul coast. Data provided by the South Atlantic Forecast Service, DHN (Brazilian Navy).

Both sampled environments, the beach-face and the backshore have a similar response to the cold front passage. However, it is at the beachface that we can identify more pronounced differences due to this meteorological event, represented in Figure 3 in terms of mean grain size, sorting, skewness and heavy mineral concentration. The overall changes in sediment characteristics due to the high energy event show a slight decrease in grain size in the middle portion of the study area (from kilometer 20 to 120 - Fig. 3a) with grain sizes increasing in the rest of the area, to the north and south. Figure $3 b$ shows that there is an overall increase in grain sorting, represented by lower standard deviation values. The grain size decrease in the middle portion of the area is a consequence of the erosion of frontal dunes, as highlighted by Calliari et al. (1998) as being an important consequence of energetic events, mainly at the region most susceptible to erosive processes, between the Sarita and Verga lighthouses. This erosive process would redistribute the finer dune grains over the beach profile. The effect of this sediment redistribution is also seen in the skewness, which presents an increase in positive values in the middle part of the area (Fig. 3c). These increasing positive skewness values confirm the addition of finer sediments to the system. These decreasing grain sizes and increase in positive skewness values after the storm are different from expected, since usually the increase in wave energy would result in coarser grain sizes along the beach. However, as mentioned above, this behaviour can be explained by the morphodynamic response of the studied beaches to storm surges associated to high energy events. This region presents unique characteristics, where variations in water levels are associated mainly to meteorological forcings. So, storm surges allow waves to reach areas that are not reached in normal tide related water level oscillations. Thereby, with the higher water levels, waves cause the erosion of the frontal dune systems, with its finer sediments being redistributed along the beach profile. Heavy mineral concentrations are also shown to be sensitive to the high-energy event, presenting an expected overall increase in its concentrations (Fig. 3d). Due to the availability of heavy minerals, the southern portion of the region (from kilometer 150 to 210 ) presents the highest concentrations, with concentrations increasing after the high-energy event. Due to its distinct hydraulic behaviour, erosive processes result in relative concentrations of these denser grains, which are left behind while the hydrodynamic conditions are able to carry lighter quartz grains. This relative increase of fine graded heavy minerals in the sediment composition of the southern portion of the study area is also reflected in an increased positive skewness (Fig. 3c). 
a

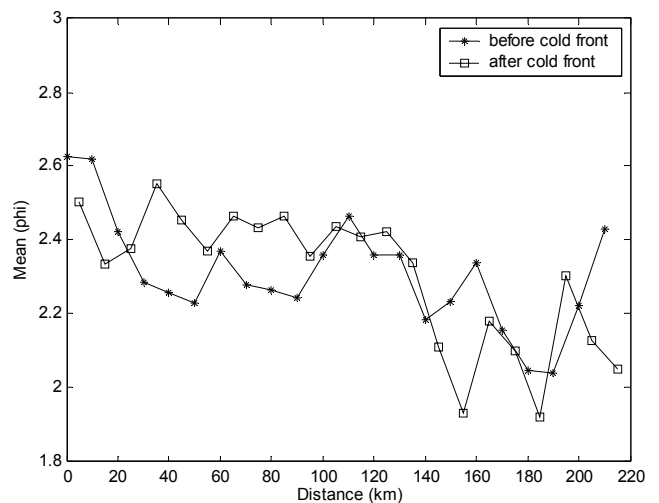

c

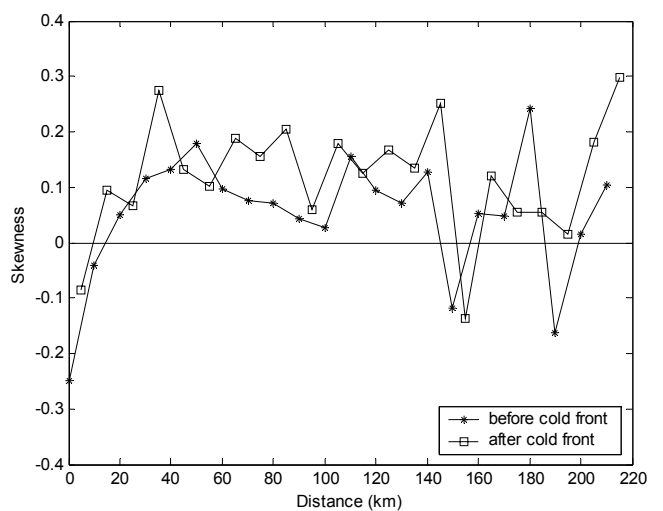

b

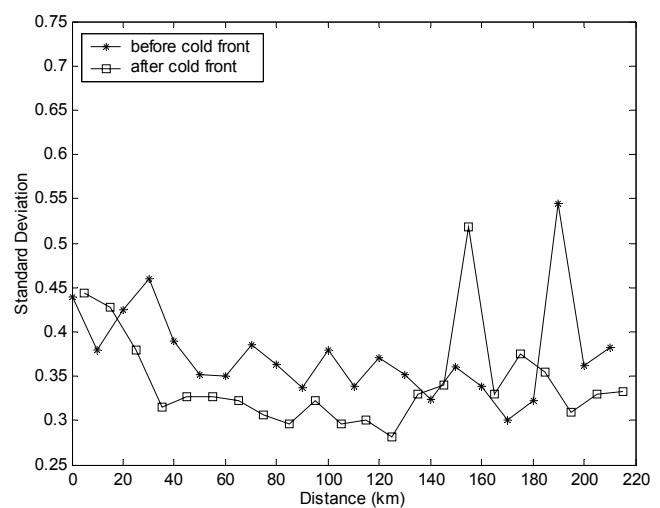

d

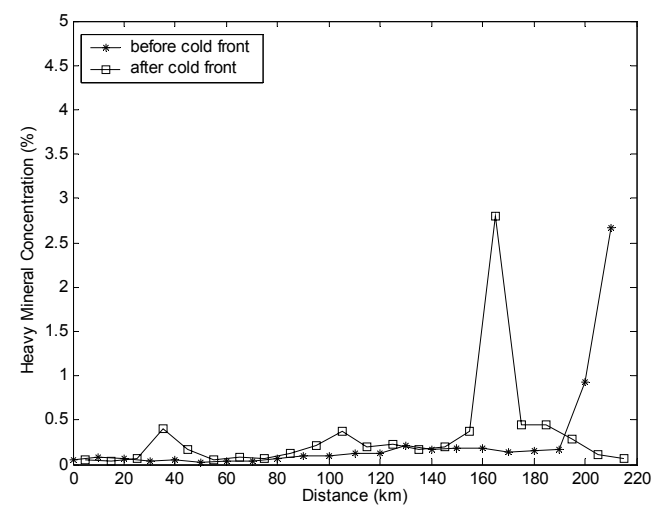

Fig. 3. Beach face sediment characteristics along the study area. From North (Cassino - 0) to South (Chuí - 220), with lighthouses located at: 60 (Sarita); 100 (Verga); 130 (Albardão); 220 (Chuí).

\section{ACKNOWLEDGEMENTS}

The authors are grateful for the financial support given by the CNPq (Conselho Nacional de Desenvolvimento Científico e Tecnológico).

\section{REFERENCES}

CALLIARI, L. J. Aspectos sedimentológicos e ambientais na região estuarial da Lagoa dos Patos. Dissertação de Mestrado (Curso de pós-graduação em Geociências), Universidade Federal do Rio Grande do Sul, 1980. 190 p.

CALlIARI, L. J.; KLEIN, A. H. F. Características morfodinâmicas e sedimentológicas das prais oceânicas entre Rio Grande do Sul e Chuí, RS. Pesquisas, v. 20, n. 1, p. 46-56, 1993.

CALLIARI, L. J.; TOZZI, H. A. M.; KLEIN, A. H. F. Beach morphology and coastline erosion associated with storm surges in southern Brazil - Rio Grande to Chuí, RS. An. Acad. Bras. Cienc., v. 70, n. 2, p. 231-247, 1998.
FIGUEIREDO, A. G. Geologia dos depósitos calcários biodetríticos da plataforma continental do Rio Grande do Sul. Dissertação de Mestrado (Curso de pósgraduação em Geociências), Universidade Federal do Rio Grande do Sul, 1975. 45 p.

FOLK, R. L.; WARD, W. C. Brazos river bar: a study in the significance of grain size parameters. J. sediment. Petrology, v. 27, n. 1, p. 3-26, 1957.

KOMAR, P. D. Beach processes and sedimentation. 2nd ed. New Jersey: Prentice Hall, 1998. 544 p.

KOMAR, P. D.; CLEMENS, K. E.; LI, Z.; SHIH, S. M. The effects of selective sorting on factor analyses of heavymineral assemblages. J sediment. Petrology, v. 59, n. 4, p 590-596, 1989.

SLINGERLAND, R. L. The effects of entrainment on the hydraulic equivalence relationships of light and heavy minerals in s ands. J sediment. Petrology, v. 47, n. 2, p. 7. 15 February 2008; accepted 18 February 2008) 